\title{
Suicidal Risk in Italian Prisons. A Population-Based Cohort Study
}

\author{
Maurizio Esposito \\ Department of Human, Social and Health Sciences, University of Cassino and Southern Lazio, Cassino, Italy \\ Email:m.esposito@unicas.it
}

How to cite this paper: Esposito, M. (2018). Suicidal Risk in Italian Prisons. A Population-Based Cohort Study. Sociology Mind, 8, 46-69.

https://doi.org/10.4236/sm.2018.81004

Received: January 7, 2018

Accepted: January 23, 2018

Published: January 26, 2018

Copyright $\odot 2018$ by author and Scientific Research Publishing Inc. This work is licensed under the Creative Commons Attribution International License (CC BY 4.0).

http://creativecommons.org/licenses/by/4.0/

\section{(c) (i) Open Access}

\begin{abstract}
The article deals with the problem of suicidal risk in Italian prisons. Beginning with a general analysis of the concept and the sociological approaches to suicide, we analyze the main studies on suicide in Italian penal institutions. We present updated Italian prisoners suicide statistics (2002-2015), which we then analyze and discuss both in absolute numbers and in percentage terms. The results indicate that the situation is critical: suicide is the leading cause of death in Italian prisons. The problem mainly affects Italian elder prisoners, the weakest group for mental and physical health. The trend data for female detainees reveal that the ability to adapt to prison life appears more difficult than for male detainees. In addition, suicide among foreign detainees has risen in recent years; a probable contributing factor is the inability to use alternative measures such as house arrest. The conclusion attests a need to provide health policies with treatment options for the cure and care of prisoners in difficulty, with a total approach responding not only to the specific symptoms or to risk behaviors but also to the whole person in a holistic sense.
\end{abstract}

\section{Keywords}

Suicide, Risk, Health, Prisons, Statistics, Overcrowding

\section{Introduction}

In this article, we present updated Italian prisoners official suicide statistics (2002-2015), which we then analyze and discuss both in absolute numbers and in percentage terms.

The term suicide (Latin sui caedere, to kill oneself) describes the act by which an individual voluntarily and consciously chooses death. Suicide is the most extreme of all self-injurious acts and is typical for conditions of severe psychologi$\mathrm{cal}$ and social distress. It is a complex problem, not attributable to a single cause 
or reason. It seems rather to result from the complex interaction of biological, genetic, psychological, social, cultural and environmental factors (Maris, 1981). For many, suicide-intentional self-murder-is the asocial act of a private individual. A sociological view grew out of Durkheim's (1951) argument that suicide rates are social facts and reflect variations in social regulation and social interaction.

The Encyclopedia of Sociology (Borgatta \& Montgomery, 2000: p. 3079) states that the earliest known visual reference to suicide is a depiction painted on an amphora from around $540 \mathrm{BC}$ of Ajax falling on his sword. And of course, it is known that Socrates drank hemlock around 399 BC. The Judeo-Christian scriptures contain eleven men (and no women) who died by suicide, most notably Samson, Judas, and Saul. Common biblical motives for suicide were revenge, shame, and defeat in battle. Famous suicides in art history include paintings of Lucretia stabbing herself after being raped, Dido, the founder and first queen of Carthage, and the works by Edvard Munch and Andy Warhol.

Suicide is currently not illegal nor punishable by law in Italy. Article 580 of the Italian Criminal Code stipulates, however, that it is an offense to incite or assist suicide, imposing higher penalties if the suicide is effective and if the suicidal person is mentally imbalanced, incapable of discernment or less than 14 years old. In these cases, the instigator is given the same punishment as for the crime of intentional homicide.

\section{Sociological Approaches to Suicidal Risk}

It's very difficult to discuss suicidal risk from a sociological point of view. We see the behavior of the person but the subjective and objective motivations remain behind hidden. We do not see the intentions, the complexity, the painful path to the act, all we are shown is their net effect. According to the Encyclopedia of Sociology, "suicide is not a single type of behavior. Suicidology will not be an exact science until it specifies its dependent variable. The predictors or causes of suicide vary immensely with the specific type of suicidal outcome" (Ivi: 3077).

The humanities today tend to consider suicide a very complex phenomenon, one which involves biological and psychological factors as well as social. The act, for example, is often preceded by states of deep depression. Causes related to the personality or circumstances may include a need to escape from intolerable situations, from a vision of life as an inevitable source of suffering that only death can quench.

For evolutionary theorists, suicide is more likely to occur when an individual feels that he has lost the opportunity to dramatically increase their inclusive fitness, that is to say, the reproductive success of the individual and the influence that he has on the reproductive success of his relatives or colony members.

Italian psychoanalyst Franco Fornari (1970) emphasizes the meta-communicative aspect of a self-injurious act, rather than seeing it as an for its own sake. He proposes that the suicidal person is desperately looking for a relation- 
ship with the world, because even if the conscious plan appears to be a denial of this contact, in fact, at a subconscious level the suicidal person is desperately seeking contact with their world. The act is therefore aimed at others in the form of a particularly dramatic emotional relationship both positive and negative. Along those lines, Beck, Kovacs, \& Weissman (1975) point out that behind the suicidal act there is both a feeling of a lack of expectation and hope for the future (hopelessness), and the impossibility of aid (helplessness). Departing from the socio-cultural and historical variables which play a role in defining suicide, Shneidman (1985), an American suicidologist, highlights several traits regarding thought, emotions and behavior common in people who attempt suicide and proposes that the general purpose of suicide is the search for a solution, that the subject feels emotional hopelessness and neglect. He defines suicide by stating that "currently in the Western world, suicide is a conscious act of self-induced annihilation, best understood as a multidimensional malaise in a needful individual who defines an issue for which suicide is perceived as the best solution." The neuropsychiatrist De Maio (1997) understands suicide as the actor's way of resolving a problem which otherwise seems unsolvable. Whether the problem be real or imagined is irrelevant, the only important aspect is how the subject experiences the situation, how they see themselves within it, how involved they feel, and that they do not see any other end to the problem other than that of their own physical annihilation.

In a sociological point of view, "much of current sociological research on suicide appears myopic and sterile compared to the early work of Durkheim, Douglas, and Garfinkel. Not only is the scope of current research limited, there is very little theory and few book-length publications" (Borgatta \& Montgomery 2000: p. 3081).

The forerunner of studies on suicide was certainly Emile Durkheim who in 1897 defined suicide as any death resulting directly or indirectly from a positive or negative act accomplished by the victim in full consciousness of producing this result. The Alsatian sociologist argued that suicide is directly proportional to social disintegration, that is to say, to the loneliness and marginalization felt by the individual. Society is absent and distant for a suicidal person, the communication, exchange and participation necessary for a subject to feel an integrated part of the community of reference is missing. Durkheim describes suicide as a social issue, not one of the individual. Seen as such, the phenomenon of suicide must then be studied under a different aspect, one that concerns not only the act intended individually but also the social factors which exercise a decisive influence, particularly those Durkheim called "anomie", or the disruption of the societal balance and the upheaval of values. This is a view, therefore, of suicide as a phenomenon linked to subjective external situations within the society, environment and groups where the person is reflected on a daily basis. The religious beliefs, family, the entire society are worthy of observation because they play prominent roles as variables influencing suicide rates. According to the general sociological law derived from Durkheim, suicide rates are inversely linked to the 
degree of integration of the individual ${ }^{1}$.

Other sociologists have studied suicide during the last century. As stated in the Encyclopedia of Sociology, "Gibbs \& Martin (1964) created the concept of "status integration"... They hypothesized that the less frequently occupied status sets would lead to lower status integration and higher suicide rates. Putting it differently, they expected integration status and suicide rates to be negatively associated" (Borgatta \& Montgomery, 2000: p. 3079).

\section{Studies on Suicides in Penal Environments}

Cinosi et al. (2013: p. 18) state that suicide risk in penal institutions is a very current and serious problem. "Suicidal behavior is more common among criminal justice clients, both among those serving community sentences and among prison inmates. Nowadays, there is great concern over the high rates of suicide and suicidal behavior in prisons, with suicide prevention becoming a major challenge for penal institutions in many countries."

In general, the literature on suicidal risk in prison outlines two different study trends, that of the medical-psychological and the sociological. These approaches offer different perspectives for the evaluation of this complex multidimensional phenomenon. Currently, however, the two approaches are not so antithetical. Indeed, "a wide variety of hypotheses have been put forward to explain high suicide rates in prisons, ranging from medical or psychiatric to sociological ones. Previous studies on the general population have shown that mental disorders are a major contributor to suicide and that key social factors associated with suicide are also measures of social disadvantage and exclusion. These factors are more frequent in prisoners than in the general population, and it is therefore not surprising that suicide rates tend to be relatively greater in prison" (Ivi: 22).

Medical research views on suicidal risk in prison are evolving. While maintaining a concentration on the pathological effect of the problem, the correlation between disease and environmental factors is emerging with increasing insistence. Medical theories depart from a study of the disease as a factor responsible for the suicide, to reach the conclusion that the penal ambient itself is pathogenic. The path begins with the examination of the individual and turns to one of the environment.

In sociological theories, the study of the penal environment is the departure point, reaching the conclusion that no matter how difficult the environmental conditions may be, not all prisoners react to it in the same way, and therefore the

${ }^{1}$ Durkheim explains the variations of suicides among groups of different religious beliefs. He noted that Protestants were more apt to suicide than Catholics or Jews. In fact, it becomes clear when studying the Catholic and Jewish ideologies that these both form compact and united societal groups where the members are never left alone in their thoughts and actions. Protestants are, however, the principal authors of their faith. The Bible is the supreme document, but no interpretation is imposed and the glory of God is the result of a long struggle. It is therefore simple to intuit the differences which make members of these beliefs either more or less susceptible to voluntary death. The first groups share a common struggle, resisting with sacrifices for existence of the community, whereas Protestants experience an individualism in their religion which renders members inexorably more vulnerable. 
personal predisposition to perform acts of self-injury must also have considerable importance. If suicide is a social phenomenon, one should not forget that this act is primarily an individual behavior. So if the sociological observation of macro-structural type, such as that undertaken by Durkheim, is essential to understanding the institutional background of the problem, it is not enough to provide an understanding of suicide in prison, which is a human behavior before it becomes a social phenomenon. It is when studying individual human behavior that we note the importance of the endogenous and exogenous factors.

The study of suicides in prisons must therefore start from an understanding of the specific case, and through this, the way the individual perceives their environment and how they react to it becomes of primary importance. It seems that it is only during this phase that the interaction of the factors contributing to the realization of suicidal behavior may be grasped, because it is only in studying the specific case that we may understand to what extent the vulnerability of the individual or the harshness of the environment contribute to carrying out the act of self-injury. It becomes important, in this perspective, to focus on what shapes the act if we want to understand the meaning of this interaction. It is also important to make use of the theories available in an interdisciplinary sense, without distinguishing between sociological, psychiatric or psychological theories, insofar as they may help reveal the meaning of single cases of suicide. Finally, this field of research requires not only quantitative but also qualitative methodologies which collect individual moments majestically and co-participatory within a narrative sense. As such, sociology can play a major paradigmatic role. As a discipline it must-according to Bauman (2014)—abandon its objectivist and nomological ghosts and instead look inside people's lives, at the lives they experience and their interactions with others.

It is not easy to describe the phenomenon of suicides in penitentiaries. Here it might be useful to return to the meanings Baechler (1979) has attributed to suicidal behavior, namely:

1) Escape: an attempt to avoid a situation experienced as intolerable;

2) Grief: the person violates his own life as a result of real or imagined loss of a loved one;

3) Punishment: to atone for an error or fault, real or imagined;

4) Crime: to force another person to accompany them in death;

5) Vengeance: to provoke remorse or community opprobrium;

6) Blackmail: to put pressure on the other redeeming;

7) Sacrifice: a cry for help in achieving a condition deemed an improvement;

8) Ordeal and play: to place themselves at risk, a type of challenge to the fates leaving the choice between life and death to a metaphysical entity.

Within these concepts, the prisoner may attribute three main meanings to the act of suicide. It may be the escape from the destructive influences the penal environment has on them, to the point where it is considered the real cause of suicide. Here the impact of the daily routine in prison undermines the personal sense of the dimensions of time and space, de-personalizing them, and suicide 
may be seen as the only escape from a destructive reality, as the prisoner's only way of retaking control of their lives. Alain Brossat (2003) describes the unwavering inertia the body of the person in custody undergoes after years in prison as "death over a slow fire". In fact, time takes on a tragically monolithic form in prison with endless repetitions and the contradictory situation where social life and leisure activities are suspended in time, yet the hours continue to pass, bringing unrelenting changes in physical appearance, a scene from Dorian Gray. If the space in the cell is in fact "closed", confined and claustrophobic, time is dilated, "open" and perceived as immovable and unchangeable. The only solutions of continuity given by the rhythms of prison (the alarm, the count, the meals, hours of air, hours of socializing, etc.), which occur without surprises, marking the inexorable days of detention.

In addition, it may be felt as a self-inflicted punishment, linked to feelings of guilt towards oneself and one's family. This sense of guilt is present above all in female prison populations and is particularly linked to their sense of negated motherhood. International research confirms the central role of motherhood in prisons, demonstrating that mothers consider separation from their children to be the hardest aspects of imprisonment, and they often feel "enormous grief" for the time lost with their children (Esposito, 2015: p. 151); according with this findings, Kupers (1999) asserts that disconnection from family is a primary reason given for suicide attempts, and more recently Fazel et al. (2008: p. 1725) show that high rates of suicides are present for married prisoners, with a Odds Ratio $=1.5$.

Finally, suicide may also be seen as an act of vengeance, a threat, blackmail, a form of prisoner rebellion. Attempting the suicide may be construed as an extreme form of transgressive behavior. Suicide as vengeance originates with hatred and a desire for revenge against everything and everyone when the prisoner feels forgotten and despised by the institutions, the community and their family; but also perhaps as a revenge against themselves, as an extreme gesture of criticism of their own acts. Through suicide, the prisoner sometimes injures himself to attack others, those deemed responsible for their detention regime. It is a way of avenging lost freedoms and rights, of their revenging their own unhappiness and frustration.

The risk of suicide among prisoners varies according to the different phases of the penal sentence term. The period of highest risk is during the first days of detention, particularly for first-time prisoners or those accused of stigmatized crimes, such as child abuse or family murders. Sometimes distressing news from outside the institution's walls, such as the withdrawal of a partner or family member, is all that is necessary to permanently upset an already precarious balance further destabilized by incarceration, leading to the decision to suicide.

If the trial ends with a sentence, the risk of suicide attempts in the period immediately afterwards is particularly critical, especially when it is a first conviction or a severe penalty has been imposed. The suicide rate is lower as the release date draws near, and these cases are generally linked to a fear of failure in post-prison life because the penal facility has paradoxically been seen as a shelter 
from a dangerous environment (Baccaro \& Morelli, 2009): the release often implies a dramatic change and a loss of landmarks, and this can be related to the family and the lack of possibility for many persons to return to live with their relatives.

The prisoner suicide rate in Italy is roughly twenty times that of the free population in Italy (Baccaro \& Morelli, 2009). The first point to consider in explanation of this abysmal gap in rates is that while detention is an extremely stressful experience for healthy prisoners, it is absolutely destructive to those whose mental stability is precarious. These findings contradict the main results of other studies (see Duthé et al., 2013), that show that the nature of crime has a larger impact than the severity of the penalty on the suicide rates. Another important point, and one usually adopted as the triggering cause of the higher number of suicides among prisoners, is the overcrowding of prisons (Huey \& Mcnulty, 2005; Mosconi, 2014: p. 80), and the psychological and physical discomfort this results in (reduced spaces, lack of intimacy, etc.). The change in the composition of prison populations must also be taken into consideration: an increase in the number of vulnerable people in prisons, in particular those Claudio Sarzotti (2007) has with effect defined as "detenuti nessuno" [the prisoner with no name] such as drug addicts and foreigners, leads to an increase of suicidal risk.

Preventing Suicide in Jails and Prisons, published by the Department of Mental Health and Substance Abuse of the World Health Organization (2007), has identified risk factors that, if present in any combination, can contribute to raising the risk of suicide among prisoners. These risk factors may be sub-divided into six groups:

- individual;

- mental health;

- environmental or situational;

- psychosocial;

- institutionalization;

- entrance trauma.

A number of studies view death as the ultimate consequence of health problems and diseases: "most mortality studies have focused on deaths occurring while in custody and showed that prisoners are more likely to die prematurely compared to people who have never been in prison, and that suicide is one of the leading causes of in-prison death" (Cinosi et al., 2013: p. 20).

To end your life in prison requires determination and an extraordinary level of despair because the tools to attempt the act do not lie at hand. Obviously, prison offers no weapons, but also no windows or balconies without railings to fall from. Suicides in Italian prisons are usually by hanging, self-asphyxiation with a plastic bag over the head, or by inhaling the gas from camping stoves used by prisoners to cook in their cells, or for overdose of medication. Bedding, socks, elastic clothing, shoe laces are all used for hanging, and window bars, railings beds, cabinets, sinks and doors are the main points used for tying the provisional cord. Self-suffocation with various objects is occasionally used, as well as bleed- 
ing to death after vein cutting, and drug overdose. The suicide attempt, to be successful, must be completed quickly, because it is difficult to be alone and unobserved in prison for long enough to complete an elaborate procedure. Suicides therefore often occur while cell-mates are in the exercise yard, while they sleep, and during periods of laxer security staffing, such as during night and weekend duty shifts.

The inconsistency of family and social support, prior suicidal behavior, a history of psychiatric illness and emotional problems are all common contributing causes. Liebling (1999) has proposed a theoretical model of the path towards suicidal behavior in prison. The model suggests that the major risk factors are all associated with the solitude of the prisoner, while the main protective factors involve contact with the family, the support of other prisoners, the presence of volunteers, a positive relationship with the staff, and partner visits. The first factor is the most significant and decisive. Loneliness is in fact a significant indicator of the likelihood of a suicide while in prisons. Isolation from family and external contacts as well as the inability to make new friends during the detention period are factors involved in the loneliness that potentially makes the prisoner more vulnerable to a suicide attempt. Incarceration results in the breakdown of the relationships of many prisoners, and bad news is not rare (Brown \& Day, 2008: p. 435). Overcrowding is widely asserted as only one of the possible causes of suicides in Italian penal institutions, with social marginality, the rupture of emotional ties and isolation named as other causes of significance (Mosconi, 2014: p. 81). Isolation is a fundamental issue, especially when combined with other problems, such as mental illnesses; in a review of Italian prison suicides, Tatarelli et al. (1999) report that $20 \%$ of inmates who attempted suicide were in isolation cells, and 40\% in single cells. More recently, Fazel et al. (2008: p. 1726) assert that at an international level a high percentage of suicides is attempted in a single cell, with a very significative Odds Ratio $(\mathrm{OR}=9.1)$. They warn that "this may be confounded by mental illness (prisoners with psychiatric diagnoses may be placed in single cells because of disturbed behavior). The use of shared accommodation for those thought to be vulnerable is an important prevention strategy".

\section{Impact of Living Conditions on Suicide Risk in Italian Prisons}

The penal population in Italy is more vulnerable and at risk than the "free" (see Esposito, 2007). Suicide rates in Italy during the past fifteen years show that intramural suicides are between 9 and 20 times those recorded in the free community (Mosconi, 2014: p. 80). This is without the additional risk of adopting specific behaviors such as alcohol abuse, smoking, drugs, promiscuous sexual activity while in custody. These unhealthy, structural, demographic and environmental conditions, present in different proportions but common to all Italian prisons, in addition to the lack of social and occupational reintegration programs for prisoners, may be of use in explaining why the prisoners often kill 
themselves: in this sense, Fazel et al. (2008: p. 1726-1727) show high rates of suicides between prisoners with alcohol problems $(\mathrm{OR}=3.0)$, with a current psychiatric diagnosis $(\mathrm{OR}=5.9)$, and receiving psychotropic medication $(\mathrm{OR}=4.2)$.

Living conditions in Italian prisons are regulated by the Penitential Law, Law 354 of 26 July 1975 "Penitential Law and the Enforcement of Custodial Measures and the Restriction of Liberty" which entered into force on 24 August 1975. Article 1 , one of the guiding principles of the Law, dictates that the penitential treatment must be humane and that it must ensure respect for human dignity. It underlines the need to implement rehabilitative processes for the accused and convicted which will support the reintegration of the prisoners into the social fabric, including contacts with the environment exterior to the prisons system. Despite the intentions of the Law, the frequent complaints and protests from prisoners in Italian prisons underlining the difficult living conditions and their state of abandon mean that incarceration has become a synonym for intolerable living conditions. The Torreggiani decision handed down by the European Court of Human Rights on 27 May 2013 gave Italy one year' s notice to adapt their penal institutions to parameters that "respect human dignity and to implement the measures necessary to avoid cases of prison overcrowding" (Manconi, Anastasia, Calderone, \& Resta, 2015: p. 33). After this decision, a sensible decrease of suicides has been recorded in Italian prisons.

An analysis of the situation in many Italian prisons produces a negative picture composed of a series of critical problems which inevitably affect the mental and physical condition of the prisoners. There exists therefore a strong relationship between the living conditions in prisons and prisoners' malaise that often results in extreme events such as suicide.

Article 6 of the Law establishes the right of prisoners to suitable accommodations, stating that the rooms or cells should be sufficiently large, lit, ventilated, heated and equipped with normal toilets which may be used in private. The cell dimensions should correspond to the number of prisoners, but due to overcrowding this requirement is often not met, compromising the health of the incarcerated persons. Prison reality is far from what is established in the statutes. The cells are small, generally designed to accommodate four people, yet often up to seven live there together, producing unsustainable living conditions. In addition, many cells lack toilet and hygiene facilities, a contravention of the provisions of Article 7 of the Penitential Regulations, Law 230 of 30 June $2000^{2}$.

An overcrowded prison implies, in addition to a lack of space and hygiene, a reduction of prisoners' activities outside of the confines of the cells due to insufficient oversight staff and suitable spaces, overloaded health care services, increased tensions and therefore more violence between the prisoners and institution staff (Rabe, 2012). Overcrowding also inevitably implies a tendency to combine different age, racial and ethnic background groupings, and amplifies the ${ }^{2}$ Article 7 1) of the Penitential Regulations states that the facilities should be placed in a compartment attached to the cell, and in 2) that the area occupied by the prisoner's hygiene facilities must be equipped with hot and cold running water, a washbasin, shower and, especially in female institutions or sections, a bidet. 
adaption problems of foreign prisoners which, in an effort to maintain a lifestyle commensurate to their customs and traditions, can lead to a feeling widespread among prisoners of being "contaminated" by contact with unwanted companions (Huey \& Mcnulty, 2005).

The above conditions are aggravated by the increase in recent years of the percentage of addicted or HIV+ prisoners; the rate of addicted inmates in Italian prisons is $21.54 \%$ (versus $2.10 \%$ in the free society), and HIV+ prevalence is $2.08 \%$ (versus $0.20 \%$ in the free society) (Esposito, 2007: p. 329). Their condition is undoubtedly difficult enough, especially if the problem of addiction is accompanied by that of HIV positive status. However, this is aggravated by the fear of contagion and leads to the addict and/or HIV positive prisoner being marginalized by the rest of the prison population.

The theme of the right to health in the penitential system has become one of enormous importance. It is usually taken for granted that the right to health, as one of man's natural rights, is respected everywhere, and that all citizens are guaranteed equal access to the various health services. This is however not the case, as evidenced by the scientific literature on the subject, for example, the rate of suicides in prison (Liebling, 1999; Watson, Stimpson, \& Hostick, 2004), or the spread of infectious diseases within the institutions (Lindquist, 2000).

\section{An analysis of Data Regarding Suicide in Italian Prisons}

Starting from the data published in the dossier Morire di carcere ${ }^{3}$ [Death by Prison], Ristretti Orizzonti Association, it will be shown that suicide is the principal cause of death in Italian prisons. The period under examination is 2002 to 2015 inclusive, and the variables considered are cause of death, age, gender and nationality. This data refers only to suicides inside prisons and jails.

The causes of death were divided into five categories: suicide, illness, causes to be ascertained, overdose, murder, and "other" indicating other causes. Table 1 and Graph 1 show that suicide represents the leading cause of death in prisons for all the years considered. In 2009, suicides behind bars soared to 72 of the 112 deaths recorded, $64 \%$ of the total. This record number is symptomatic of an increasingly worrying situation in prisons. Beyond 2009, a critical year was also 2010, with 66 suicides from 101 deaths, $65 \%$ of the total. The lowest numbers were recorded in 2002 and 2008 with 36 cases in each year. Between 2006 and 2008 there was a clear drop in the number of deaths in custody and a corresponding decrease in suicides. It should be borne in mind that the General

\footnotetext{
${ }^{3}$ Morire di carcere represents an important contribution to improving public awareness of the real conditions in prisons, beginning with the difficulties and, often, state of abandonment that the prisoners find themselves in. The dossier consists of three parts; the first is made up of accounts of prison deaths due to suicides, illness, drug overdose and for unknown reasons. A second section presents news and thoughts derived from prison newspapers, information from prisoners who knew the deceased, sometimes as a cellmate, in addition to materials taken from surveys of associations engaged in defending civil rights. The last part consists of summary tables listing the deceased prisoners, their ages and why they died, and the prisons where the death occurred. Consultable under: http://www.ristretti.it/areestudio/disagio/ricerca/
} 
Table 1. Causes of death. Absolute numbers.

\begin{tabular}{|c|c|c|c|c|c|c|c|c|c|c|c|c|c|c|c|}
\hline \multirow{2}{*}{$\begin{array}{c}\text { Causes of } \\
\text { death }\end{array}$} & \multicolumn{15}{|c|}{ Years } \\
\hline & 2002 & 2003 & 2004 & 2005 & 2006 & 2007 & 2008 & 2009 & 2010 & 2011 & 2012 & 2013 & 2014 & 2015 & Total \\
\hline Suicide & 36 & 43 & 54 & 55 & 48 & 43 & 36 & 72 & 66 & 66 & 60 & 49 & 44 & 44 & 716 \\
\hline Disease & 16 & 8 & 26 & 20 & 12 & 20 & 20 & 22 & 22 & 19 & 11 & 26 & 21 & 24 & 267 \\
\hline Unknown & 13 & 8 & 11 & 22 & 9 & 10 & 32 & 17 & 11 & 22 & 35 & 24 & 12 & 23 & 249 \\
\hline Overdose & 3 & 4 & 4 & 4 & 4 & 4 & 0 & 0 & 2 & 1 & 2 & 1 & 1 & 3 & 33 \\
\hline Murder & 0 & 0 & 2 & 4 & 0 & 3 & 0 & 1 & 0 & 1 & 2 & 0 & 0 & 1 & 14 \\
\hline Other & 0 & 0 & 0 & 0 & 0 & 0 & 0 & 0 & 0 & 0 & 1 & 0 & 0 & 0 & 1 \\
\hline Total & 68 & 63 & 97 & 105 & 73 & 80 & 88 & 112 & 101 & 109 & 111 & 100 & 78 & 95 & 1280 \\
\hline
\end{tabular}

\section{Causes of death}

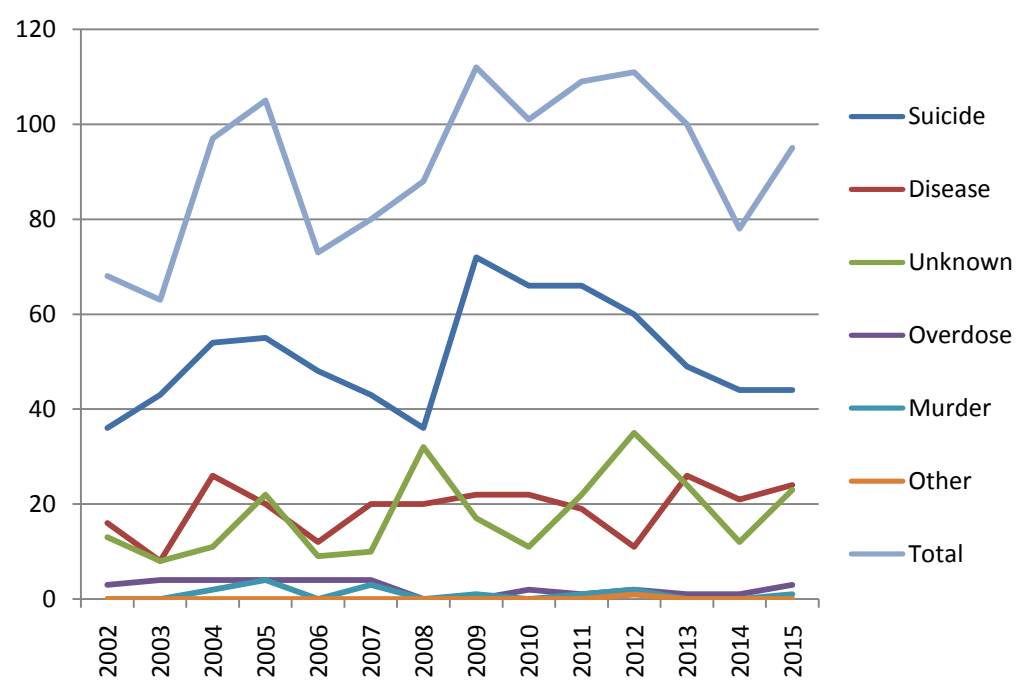

Graph 1. Suicides. Absolute numbers.

Pardon Law 241 of 31 July 2006 was enacted during this period, dramatically decreasing the prison population. In percentage terms, the data from 2006 to 2008 significantly decreases (see Table 2 and Graph 2), demonstrating that a reduction of the general population also leads to greater wellbeing in prison.

This trend to decrease recurs in recent years, in particular since 2011, and is probably due to Law 199 of 26 November 2010 which sets out the provisions relating to the implementation of custody within the domicile of the prisoner for sentences no longer than 18 months, and of Decree Law 211 of 22 December 2011, the so-called "empty the jails" decree, a finding confirmed also at a proportional level. These trends show the correlation between suicides and overcrowding, as asserted supra by scientific literature on this topic.

In summary, a significant growth trend can be seen for prison suicides during the period 2004 to 2005, before falling from 2006 through to 2008. The rate increase registered in 2009 declines again in the following years. 
Table 2. Suicides. Rate on 10.000 .

\begin{tabular}{ccccccccccccccc}
\hline & 2002 & 2003 & 2004 & 2005 & 2006 & 2007 & 2008 & 2009 & 2010 & 2011 & 2012 & 2013 & 2014 & 2015 \\
\hline Suicide & 36 & 43 & 54 & 55 & 48 & 43 & 36 & 72 & 66 & 66 & 60 & 49 & 44 & 44 \\
Pop tot & 55.670 & 54.237 & 56.068 & 59.523 & 39.005 & 48.693 & 58.127 & 64.791 & 67.961 & 66.897 & 65.701 & 62.536 & 53.623 & 52.164 \\
Rate suicide & 6.47 & 7.93 & 9.63 & 9.24 & 12.31 & 8.83 & 6.19 & 11.1 & 9.71 & 9.87 & 9.13 & 7.84 & 8.21 & 8.43 \\
\hline
\end{tabular}

\section{Rate suicides}

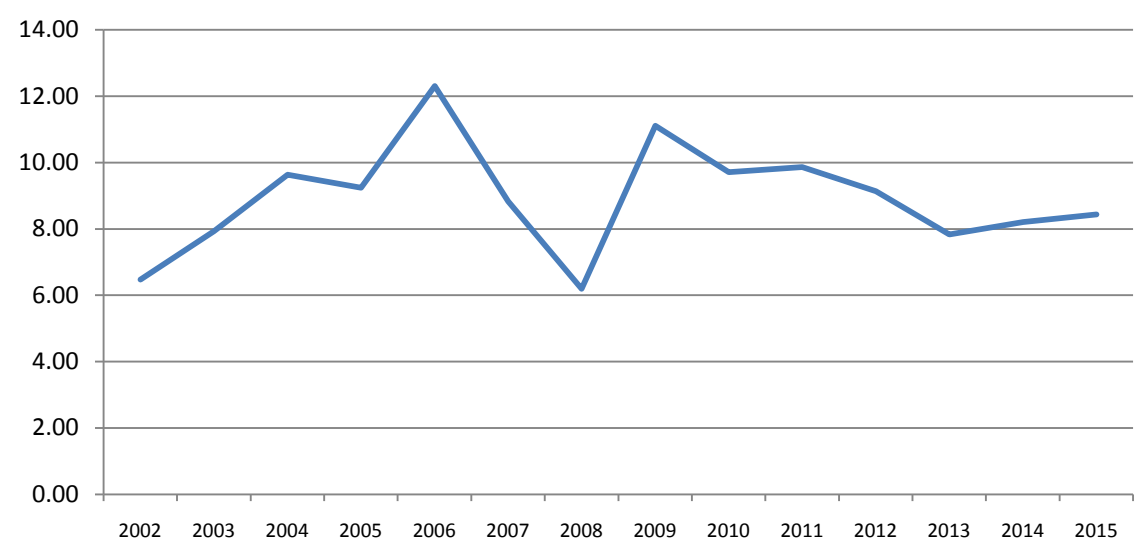

Graph 2. Suicides. Rate on 10.000 .

The most relevant data for deaths from disease are those concerning 2004 and 2013 when 26 deaths are recorded for each year, with the number rising again in 2015. Here it should be noted that, in contrast to the general data and those related to suicide-both of which have declined appreciably in recent years-data for death by disease remains fairly constant over time, evidence of a need to reconsider Italian health system models.

Another interesting fact regards deaths for reasons yet to be ascertained. The years 2008 and 2012 record the highest numbers of these deaths respectively 32 and 35 . The trend for deaths by overdose and murder remains fairly constant for all the years in question. However, the data are too sporadic to allow a reliable and meaningful interpretation. Only one death, in 2012, was the result of a hunger strike.

The second variable considered is the age of prisoners. As seen from Table 3 and Graph 3, suiciding prisoners belong in the main to the first two age groups, 29 - 39 and 40 - 50 years, with a total of 246 suicides for the first and 195 for the second. The data shows that a higher percentage of suicides is attempted by middle-aged prisoners, contradicting the argument that younger prisoners, facing the harsh realities of prison life for the first time, do not succeed in recovering from the shock upon entry and that this may develop into a verifiable trauma (Shaw, Baker, \& Hunt, 2004). The trauma observed appears more likely to be linked to other factors such as the length of the sentence or personal characteristics of the prisoners rather than their recorded age. As can be seen, the 
Table 3. Age of suicide. Absolute numbers.

\begin{tabular}{|c|c|c|c|c|c|c|c|c|c|c|c|c|c|c|c|}
\hline \multirow{2}{*}{ Age } & \multicolumn{14}{|c|}{ Years } & \multirow[b]{2}{*}{ Total } \\
\hline & 2002 & 2003 & 2004 & 2005 & 2006 & 2007 & 2008 & 2009 & 2010 & 2011 & 2012 & 2013 & 2014 & 2015 & \\
\hline $18-28$ & 13 & 17 & 10 & 12 & 8 & 10 & 10 & 17 & 16 & 13 & 15 & 10 & 4 & 10 & 165 \\
\hline $29-39$ & 12 & 16 & 17 & 19 & 17 & 15 & 12 & 30 & 24 & 25 & 17 & 13 & 17 & 12 & 246 \\
\hline $40-50$ & 9 & 9 & 18 & 12 & 17 & 11 & 10 & 19 & 17 & 16 & 15 & 15 & 15 & 12 & 195 \\
\hline $51-61$ & 1 & 1 & 6 & 8 & 5 & 5 & 4 & 5 & 7 & 6 & 11 & 9 & 5 & 8 & 81 \\
\hline $62-72$ & 1 & 0 & 2 & 3 & 1 & 2 & 0 & 1 & 2 & 4 & 2 & 2 & 3 & 2 & 25 \\
\hline $73-83$ & 0 & 0 & 1 & 1 & 0 & 0 & 0 & 0 & 0 & 2 & 0 & 0 & 0 & 0 & 4 \\
\hline Total & 36 & 43 & 54 & 55 & 48 & 43 & 36 & 72 & 66 & 66 & 60 & 49 & 44 & 44 & 716 \\
\hline
\end{tabular}

\section{Age at suicide}

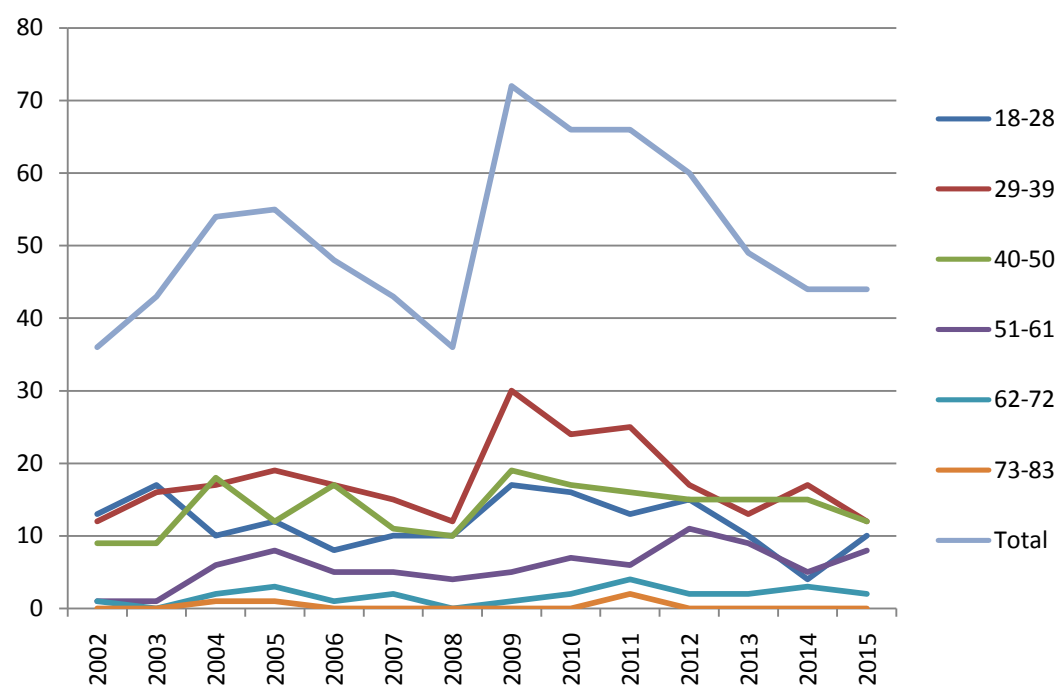

Graph 3. Age. Absolute numbers.

diachronic data sums up total suicides, with a peak in 2009 (which mainly affects the age group 29 - 39 years) and a corresponding downward trend from 2012. It should also be noted that the number of suicides in the youngest group (18 - 28 years) was higher than those of other groups in 2002 and 2003, a number which normalized gradually over time.

In percentage terms (our data start from year 2005 due to lack of data for previous years), it is very interesting to note in Table 4 and Graph 4 that-if we exclude the 73 - 83 age group for too few numbers-the most exposed to suicide in prison is the group 40 - 50 years old, especially in year $2006(18.51 / 10.000)$ and the range $62-72$ years old, with two very significant peaks in 2005 (16.8/10.000) and 2011 (14.99/10.000). This confirms that the old age has a greater impact than the young age on the individual's wellbeing and on his mental and physical health. 
Table 4. Age of suicide. Rate on 10.000 .

\begin{tabular}{lccccccccccc}
\hline & 2005 & 2006 & 2007 & 2008 & 2009 & 2010 & 2011 & 2012 & 2013 & 2014 & 2015 \\
\hline $18-28$ & 7.61 & 7.70 & 7.05 & 6.07 & 9.57 & 9.05 & 7.82 & 9.78 & 7.22 & 3.65 & 9.57 \\
$29-39$ & 8.75 & 12.71 & 9.06 & 6.09 & 13.59 & 10.45 & 11.19 & 7.89 & 6.45 & 10.20 & 7.60 \\
$40-50$ & 8.77 & 18.51 & 10.04 & 7.41 & 12.45 & 10.5 & 9.67 & 8.83 & 9.11 & 10.39 & 8.45 \\
$51-61$ & 13.00 & 11.64 & 9,87 & 6,53 & 7.16 & 9.08 & 7.39 & 13.15 & 10.62 & 6.25 & 9.99 \\
$62-72$ & 1.80 & 7.16 & 12.85 & 0.00 & 4.54 & 8.04 & 14.99 & 7.02 & 6.80 & 10.18 & 6.50 \\
\hline
\end{tabular}

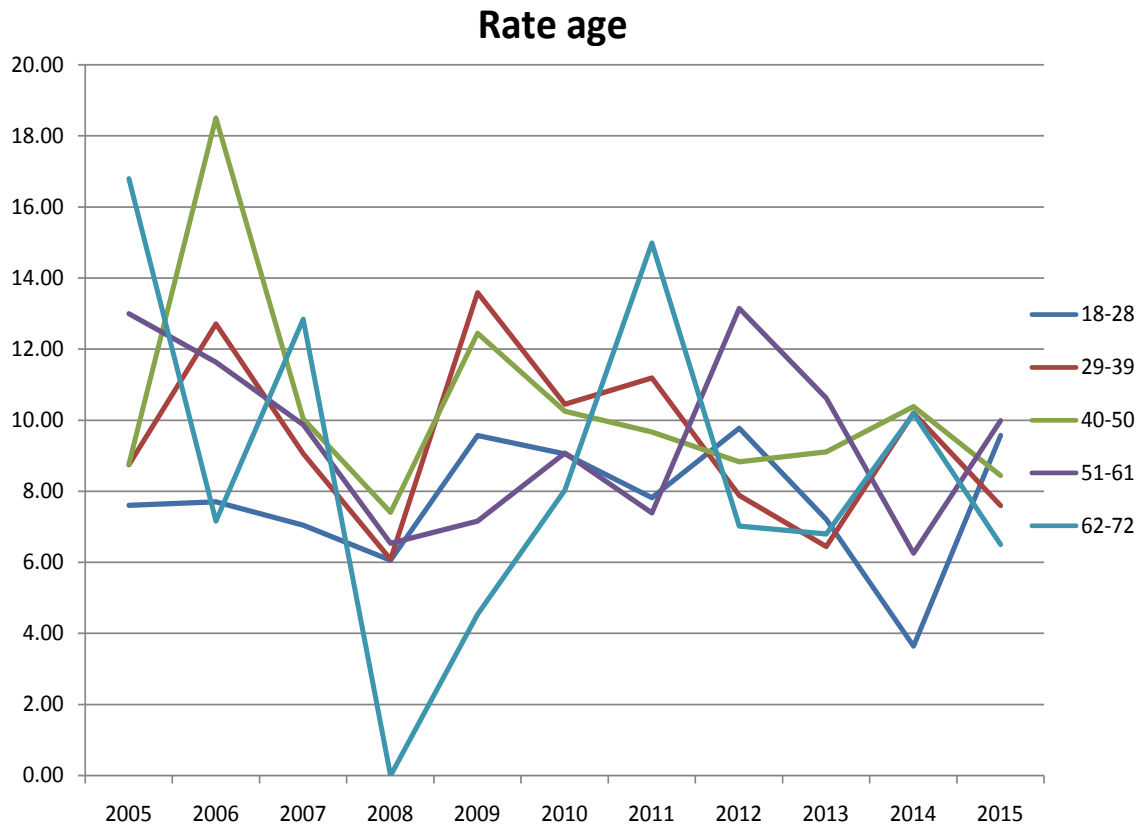

Graph 4. Age. Rate on 10.000 .

Elderly people in prison have been described as a "forgotten minority" (Ham, 1976; Goetting, 1983). They, given the weakness and frailty of their psycho-physical condition, are often victims of aggressive attitudes on the part of the younger (Krajick, 1979). Among the most common psychosocial effects for this segment of the population, the Goetting (1983) enumerates three in particular: dependence on the institution, self-perception of one's age, dissatisfaction; more specifically, the "core" variable seems to be the state of health than age in itself. Indeed, older prisoners generally have a more compromised health and a higher proportion of mental disorders and drug abuse behaviors than younger prisoners (see Harris, Hek, \& Condon, 2007).

The third variable taken into consideration was the gender of the prisoners who attempt suicide. As can be seen from Table 5 and Graph 5, the number of male suicides is significantly higher than that for female prisoners for the same periods. Moreover, while the figure for men follows general data trends, data show that for females as remaining relatively constant over time. Again, the years 2009, 2010 and 2011 are the most critical with totals of 68,63 and 63 
Table 5. Gender and suicide. Absolute numbers.

\begin{tabular}{lcc}
\hline & & Suicides \\
\cline { 2 - 3 } Years & Male & Female \\
\hline 2002 & 33 & 3 \\
2003 & 42 & 1 \\
2005 & 49 & 5 \\
2006 & 53 & 2 \\
2007 & 46 & 2 \\
2008 & 40 & 3 \\
2009 & 32 & 4 \\
2010 & 68 & 4 \\
2011 & 63 & 3 \\
2012 & 63 & 3 \\
2013 & 57 & 3 \\
2014 & 49 & 0 \\
2015 & 41 & 3 \\
\hline & 41 & 3 \\
\hline
\end{tabular}

\section{Gender and suicide}

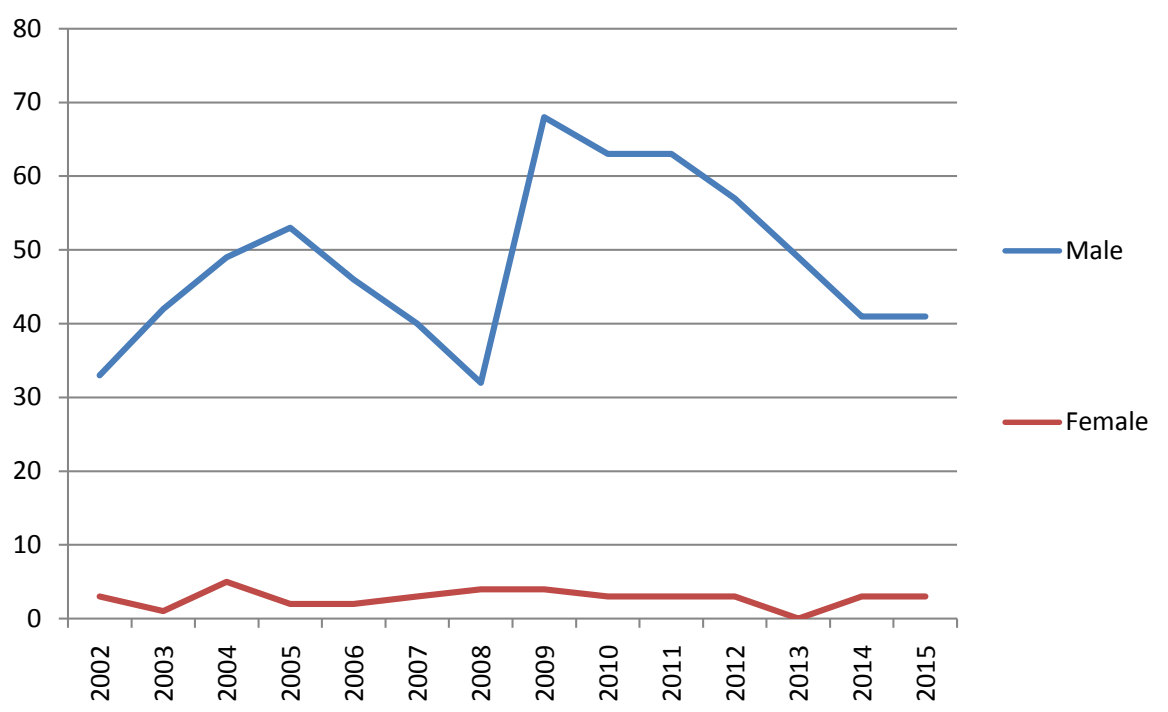

Graph 5. Gender. Absolute numbers.

deaths among male prisoners. The highest number of female suicides recorded is 5 in 2004.

The raw numbers are to be read bearing in mind that the male prison population is significantly higher than the female prison population. The Italian Ministry of Justice records an average female presence of approximately $4 \%$ of the total for the years considered. This data is in line with data from other European 
countries. Adjusted for percentages, the numbers are quite alarming, a trend in contrast with the study of Fazel et al. (2008), which at an international level show the rate of suicide for men higher than for the female population $(\mathrm{OR}=1.9)$.

Suicide seems to be an especially female characteristic, further proof of the difficulty that this population has in experiencing penal life (Paton \& Jenkins, 2005). In particular, the most critical years-adjusting the data for percentages-are 2008 (11.1\% of the suicides of women of total suicides), 2004 (9.2\%), and 2002 (8.3\%), as we can see in Table 6 and Graph 6. Even with this adjustment, the suicide totals for the female prison population do not follow the downward trend of the male, an invitation to political institutions to consider the implementation of medical and educational intervention programs targeted specifically at females.

Indeed, the small number of women's prisons means that sections for females are a necessary inclusion in male institutions. However, this same situation means that female prisoners feel forgotten, especially by intramural medical and educational programs targeted at the average male. The small numbers of female prisoners, in fact, does not allow the realization of projects related to educational or professional courses or, in any case, projects aimed especially at women. Indeed "being a minority within a minority, being equal but different, being forgotten because not important for statistics: this is the condition that women locked up in prison are forced to serve along with their sentence, living in an universe conceived and organized on the needs and characteristics of the average male prisoner" (Esposito, 2015: p. 138). In addition, female prisoners may

Table 6. Gender. Percentages.

\begin{tabular}{|c|c|c|c|c|}
\hline & Male & Female & $\begin{array}{l}\text { Percentage female on } \\
\text { total suicides }\end{array}$ & $\begin{array}{l}\text { Percentage female } \\
\text { on total population }\end{array}$ \\
\hline 2002 & 33 & 3 & 8.3 & 4.44 \\
\hline 2003 & 42 & 1 & 2.3 & 4.60 \\
\hline 2004 & 49 & 5 & 9.2 & 4.62 \\
\hline 2005 & 53 & 2 & 3.6 & 4.71 \\
\hline 2006 & 46 & 2 & 4.1 & 4.28 \\
\hline 2007 & 40 & 3 & 7.5 & 4.47 \\
\hline 2008 & 32 & 4 & 11.1 & 4.35 \\
\hline 2009 & 68 & 4 & 5.5 & 4.12 \\
\hline 2010 & 63 & 3 & 4.5 & 4.32 \\
\hline 2011 & 63 & 3 & 4.5 & 4.20 \\
\hline 2012 & 57 & 3 & 5 & 4.27 \\
\hline 2013 & 49 & 0 & 0 & 4.31 \\
\hline 2014 & 41 & 3 & 6.8 & 4.30 \\
\hline 2015 & 41 & 3 & 6.8 & 4.04 \\
\hline
\end{tabular}




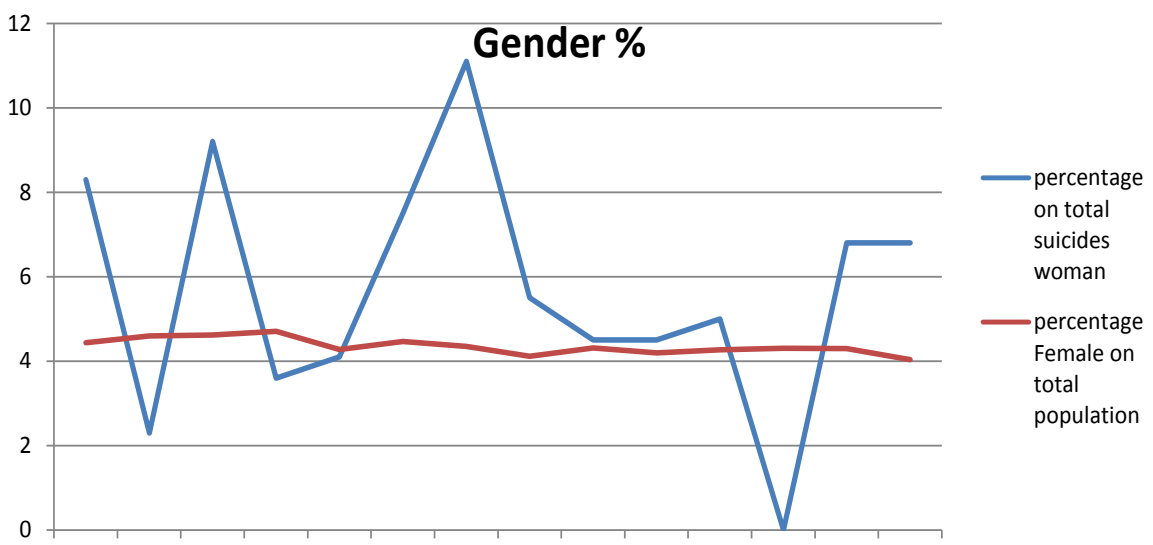

20022003200420052006200720082009201020112012201320142015

Graph 6. Gender. Percentages.

tolerate the punitive condition and the enforced security measures on average less than male prisoners (Malloch, 2000), giving rise to self-destructive acts which may lead to the risk of suicidal behaviors.

The nationality of the suicides in Italian prisons is the fourth variable considered in the dossier. The highest numbers of suicides by Italian prisoners were recorded in 2010, 2009 and 2004 (see Table 7 and Graph 7), numbering respectively 49,48 and 48 cases. A sharp increase in suicides by foreigners prisoners in Italian prisons is noted for the years 2009, 2011 and 2013, with 24 cases per year. This increase is similar to that observed for Italian prisoners, and in fact in 2013, suicides for Italians and foreigners are almost equal. Data demonstrate the similarity between the prisoners suicide trends and that of the Italian population in general, while an interpretation of the trend among the foreign prisoners from 2009 (when there was a decisive increase) proves more complex and difficult. Of additional concern is the fact that while the number of suicides by Italian prisoners in 2015 (the last year recorded) decreased significantly, that of foreigners increased by more than double.

The arguments presented when analyzing the gender variable must also be remembered here. The prison population is mostly made up of Italian prisoners, while foreign prisoners are in the minority, noting in addition that the percentage has decreased. So therefore, if the suicide rate among foreigners seems pretty steady in absolute values, their proportion of total suicides has increased significantly since 2009 , peaking in 2013 when 24 suicides were attempted by foreign prisoners and 25 by Italians, corresponding to $49 \%$ of the total. This may be attributed to a poorer integration of the foreign prisoner into the prison environment as well as a reduced ability to access rehabilitative measures, and to the difficulty in obtaining access to alternative measures to prison such as house arrest, obviously not an alternative for prisoners without a residence permit. The suicide rate among foreign prisoners (see Table 8 and Graph 8 ) is always below the percentage of attendance, with the exception of year 2013. 
Table 7. Nationality and suicide. Absolute numbers.

\begin{tabular}{lcc}
\hline & \multicolumn{2}{c}{ Suicides } \\
\cline { 2 - 3 } Years & Italian & Foreign \\
\hline 2002 & 33 & 3 \\
2003 & 41 & 2 \\
2005 & 48 & 6 \\
2006 & 45 & 10 \\
2007 & 40 & 8 \\
2008 & 29 & 14 \\
2009 & 28 & 8 \\
2010 & 48 & 24 \\
2011 & 49 & 17 \\
2012 & 42 & 24 \\
2013 & 40 & 20 \\
2014 & 25 & 24 \\
2015 & 38 & 6 \\
\hline & 31 & 13 \\
\hline
\end{tabular}

\section{Nationality and suicide}

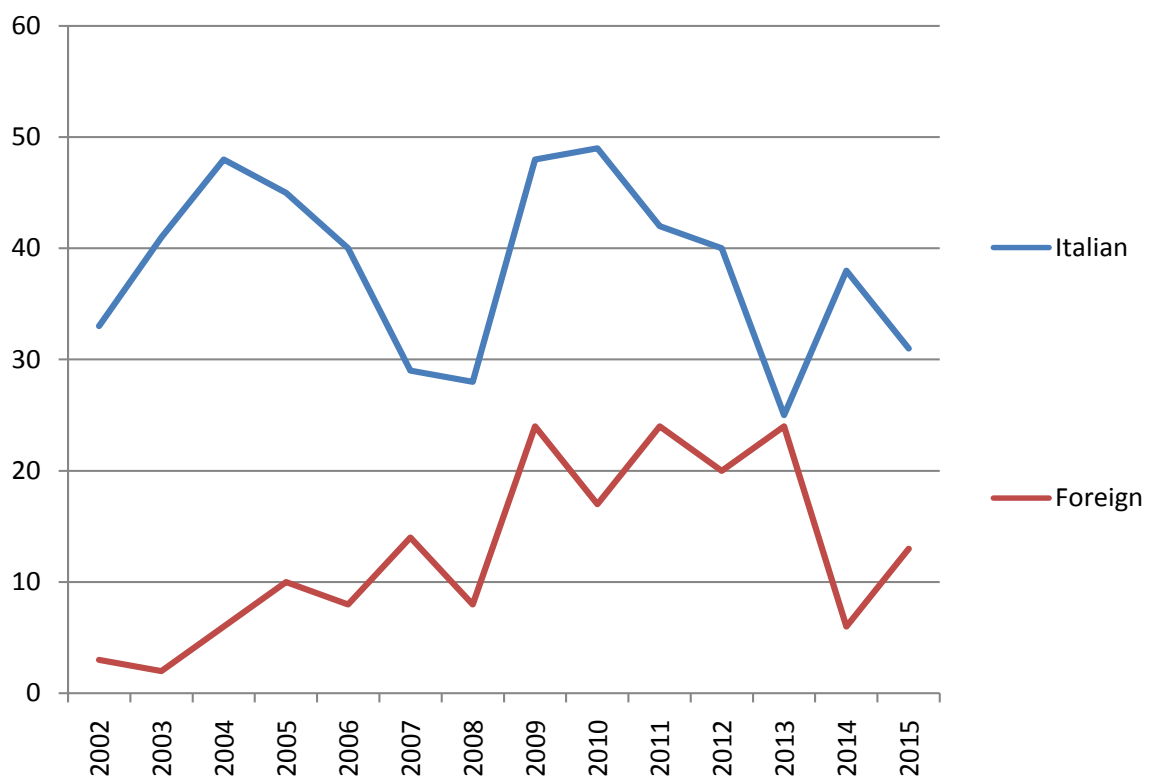

Graph 7. Strangers. Absolute numbers.

\section{Conclusion}

The analysis affirms that suicide was the leading cause of death in Italian penal institutions from 2002 to 2015. The data is clearly alarming, but is in line with European-level data updated to 2007 (Council of Europe, 2009), where Italy ranks fourth for the number of suicides after France, Germany and England. 
Table 8. Strangers. Percentages.

\begin{tabular}{lcccc}
\hline & Italian & Foreign & $\begin{array}{c}\text { Percentage strangers } \\
\text { on total suicides }\end{array}$ & $\begin{array}{c}\text { Percentage strangers } \\
\text { on total population }\end{array}$ \\
\hline 2002 & 33 & 3 & 8.3 & 30.16 \\
2003 & 41 & 2 & 4.6 & 31.36 \\
2004 & 48 & 6 & 11.1 & 31.78 \\
2005 & 45 & 10 & 18.2 & 33.32 \\
2006 & 40 & 8 & 16.6 & 33.72 \\
2007 & 29 & 14 & 32.5 & 37.48 \\
2008 & 28 & 8 & 22.2 & 37.09 \\
2009 & 48 & 24 & 33.3 & 37.15 \\
2010 & 49 & 17 & 25.7 & 36.72 \\
2011 & 42 & 24 & 36.3 & 36.14 \\
2012 & 40 & 20 & 33.3 & 35.76 \\
2013 & 25 & 24 & 49 & 34.95 \\
2014 & 38 & 6 & 13.6 & 32.56 \\
2015 & 31 & 13 & 29.5 & 33.24 \\
\hline
\end{tabular}

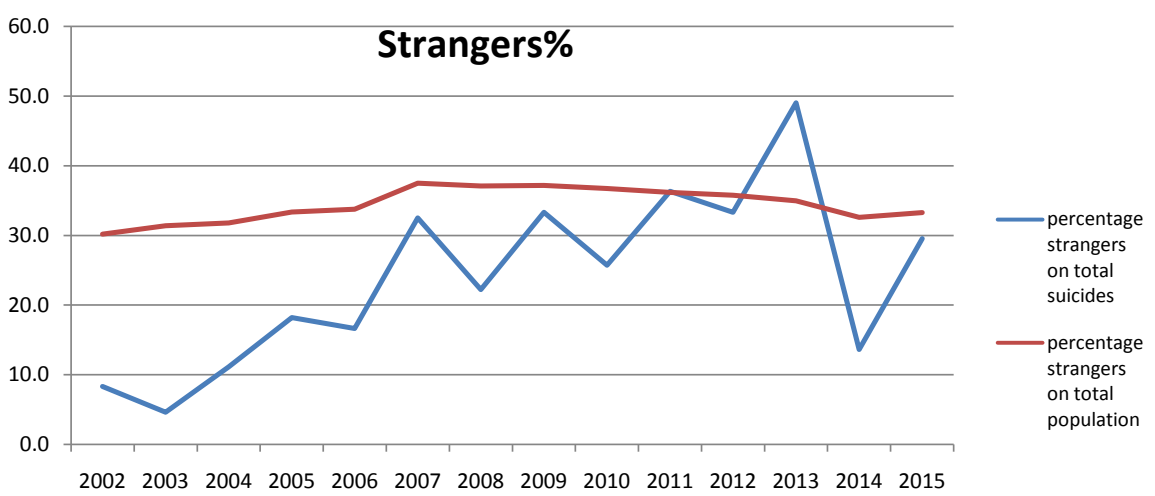

Graph 8. Strangers. Percentages.

As recently noted (Esposito, 2016), above all in situations where the prisoner lacks an external goal-obviously this is primarily a relational motivation connected to family life-any anger is turned inwards, and in extreme cases and sadly very commonly this inward anger may spark a reaction of self-destruction which moves from apathy to depression, culminating fatally in suicidal risks ${ }^{4}$.

A high concentration of vulnerable groups at risk of suicide can be found in Italian penal institutions. This includes those who have committed crimes with a

${ }^{4}$ The Russian writer Viktor L'vovič Kibal' čič, better known as Victor Serge, describes his feeling of existential apathy as such "Here I am back in a cell. Alone. Minutes, hours, days slip away with terrifying insubstantiality. Months will pass away like this, and years. Life! The problem of time is everything. Nothing distinguishes one hour from the next: the minutes and hours fall slowly, torturously. Once past, they vanish into near nothingness. The present minute is infinite. But time does not exist" (Serge, 1970: p. 30). 
high degree of violence, who are undergoing psychopharmacological treatment, are prone to suicidal behaviors, drug addicts and those who are mentally ill (see Fazel et al., 2008: p. 1726). Other elements of vulnerability are found frequently in prison populations, such as predominantly negative moods, an inability to handle psychological stress, low socio-cultural skills, insufficient coping resources when confronting difficult situations, low levels of self-esteem, high levels of anxiety, poor impulse control, an inability to manage emotions, and a tendency to alternate between elation and despair.

International research confirms the main risk factors for suicidal behaviors: the organization of the penal institution, its culture and the relationships it may trigger may in fact play an important causal factor in the contraction of diseases (McCallum, 1995), and more recently, Marshall, Simpson, \& Stevens (2000) demonstrate what conditions such as a lack of privacy, overcrowding, social isolation, the set routine and the lack of stimuli may produce or worsen in the physical and mental state of the person in custody, in particular regarding depression, anxiety, drug use, violence, self-harm and suicide attempts.

Indeed "whatever individual stressors, vulnerabilities and situational factors may be operating, it seems that feelings of hopelessness, a narrowing of future prospects and a loss failure of coping mechanisms ultimately lead prisoners to attempt suicide. Suicide is perceived as the only way out of a desperate and hopeless situation" (Cinosi et al., 2013: pp. 23-24). In this sense, overcrowding plays a fundamental role as a risk factor, as our data show. As asserted at an international level, "several studies support the hypothesis that the stress of crowding - and the accompanying struggles for resources, space, and personal autonomy-create atmospheres that impede inmate adaptation to prison life and increase the likelihood of suicide" (Huey \& Mcnulty, 2005: p. 494).

Moreover, a key effect which penal institutions have on those who cross its thresholds is the process of institutionalization. Prisoners are subjected to a process which strips them of their idea of self, they are separated from their original environment and from any other part of their identity. Imprisonment results in the loss of the individual's freedom to manage their own existence, to plan activities and the timing of their implementation. Inside the prison, time and space must pass in accordance with the rules imposed, independent of the will, desires or needs of the prisoner. These rules lead to risk consequences such as feeling of depersonalization in the person, an identity crisis and a reduction of self-esteem. A penal institution absorbs within itself the individuals who enter its confines, depriving them of any identity and sometimes their personality, to leave them in a kind of "existential impasse" (Benasayag \& Schmit, 2005: p. 48). This effect has been clearly identified as a "process of mortification" (Goffman, 1961), during which the self-esteem and the possibilities for self-realization are severely compromised, or even as a "process of normalization" (Foucault, 1975), whereby prisoners are so deprived of their autonomy, responsibility and identity that they deny their own dignity, adapting as much as possible to the internal 
rules of the total institution ${ }^{5}$. In this sense, for our topic, "deprivation theory predicts that prisons in which inmates experience a greater loss of freedom, have lesser control over daily routines, and have denied access to rehabilitative programs will have a higher incidence of suicide" (Huey \& Mcnulty, 2005: p. 491).

Furthermore, the commencement of the detention and life as a recluse may lead to a modification of the social image and, often, a negative view of society as a whole. In most cases, this remains unaltered after the period of incarceration and the return to freedom. Donald Clemmer (1940) terms this process "prisonization", the overall effect the penal experience has on the individual prison experience where a habituation to the "folkways, mores, customs and general culture of the penitentiary" occur, a gradual process of acculturation to the prison community culminating in a more or less complete identification with it.

In light of this, and in line with the WHO document (World Health Organization, 2007: p. 22), we must therefore proceed in a coordinated manner in various sectors to:

1) Promote staff training programs and refresher courses, in particular for penal institution staff and health professionals;

2) Examine the prison environment with greater attention, reassessing the activities, safety, culture, and especially the relationships between staff and prisoner. The prison social climate is of considerable importance in reducing suicidal behavior, and in particular the quality of the staff-prisoner relationship which must be characterized by empathy and support.

3) Activate procedures for systematic screening of prisoners, both on entry and periodically during the incarceration, in order to identify those at higher risk;

4) Propose strategies to facilitate communication and information between the penal institution staff;

5) Ensure psychiatric care and specialized oversight for prisoners with mental disorders;

6) Implement debriefing strategies when suicide cases occur, to improve the detection of future attempts and the observation and management of prisoners.

In particular, it should be fundamental to increase the involvement of the inmates in rehabilitative programs. This participation "would foster a more tolera${ }^{5}$ Erving Goffman (1961), in Asylums, elaborates the definition of Total Institutions: there, social relationships and contacts with the external world are completely forbidden and impossible, often determined by the physical structure of the institution: locked doors, high walls, barbed wire. The modern individual tends to sleep, play and work in different contexts. The main differences in the total institution are three: "First, all aspects of life are conducted in the same place and under the same central authority. Second, each phase of the member's daily activities is carried on in the immediate company of a large batch, all of whom are treated alike and required to do the same thing together. Third, all phases of the day's activities are strictly scheduled, with one activity leading at a prearranged time into the next, the whole sequence of activities being imposed from above by a system of explicit formal rulings and a body of officials. Finally, the various enforced activities are brought together into a single rational plan, purportedly designed in order to fulfill the official purpose of the institution." According to the Canadian sociologist, the purpose of the total institution is to cancel the individual's personal identity, ruling not one part of his activities, but his entire existence, forcing him to become "a genius of survival". 
ble atmosphere (for correctional staff as well) by reducing idleness and frustration and would provide inmates with relevant skills as well as a sense of meaning and possibility" (Huey \& Mcnulty, 2005: p. 508).

To conclude, the practical social significance of this article consists in providing data that indicate the necessity to implement interventions in Italian penal institutions designed to prevent and reduce the number of suicides. Specific personnel are required, adequately trained and skilled experts, especially psychologists and educators, able to support the prisoner including during the most difficult periods and where the greatest problems surface. These specialists should be capable of responding to the prisoner as a whole person, and not merely to the single symptoms as they occur. At the same time, the many general structural problems which currently exist in Italian penal institutions must be tackled more vigorously.

\section{References}

Baccaro, L., \& Morelli, F. (2009). In carcere: Del suicidio ed altre fughe. Padova: Logos edizioni.

Baechler, J. (1979). Suicides. New York: Basic Books.

Bauman, Z. (2014). La scienza della libertà. A cosa serve la sociologia. Trento: Erickson.

Beck, A. T., Kovacs, M., \& Weissman, A. (1975). Hopelessness and Suicidal Behaviour: An Overview. The Journal of the American Medical Association, 234, 1146-1149. https://doi.org/10.1001/jama.1975.03260240050026

Benasayag, M., \& Schmit, G. (2005). L'epoca delle passioni tristi. Milano: Feltrinelli.

Borgatta, E. F., \& Montgomery, R. J. V. (2000). Encyclopedia of Sociology. New York: Macmillan.

Brossat, A. (2003). Scarcerare la società. Milano: Elèuthera.

Brown, S., \& Day, A. (2008). The Role of Loneliness in Prison Suicide Prevention and Management. Journal of Offender Rehabilitation, 47, 433-449.

https://doi.org/10.1080/10509670801992459

Cinosi, E. et al. (2013). Suicide in Detainees: An Italian Contribute. The Open Criminology Journal, 6, 18-29. https://doi.org/10.2174/1874917801306010018

Clemmer, D. (1940). Prisonization. San Francisco, CA: Freeman.

Council of Europe (2009). Annual Penal Statistics-Space I. Strasbourg: Council of Europe.

De Maio, D. (1997). Il suicidio, compendio storico, clinico-casistico, biologico e terapeutico. Roma: Il Pensiero Scientifico Editore.

Durkheim, E. (1951). Suicide. New York: Free Press.

Duthé, G. et al. (2013). Suicide among Male Prisoners in France: A Prospective Population-Based Study. Forensic Science International, 233, 273-277.

https://doi.org/10.1016/j.forsciint.2013.09.014

Esposito, M. (2007). Malati in carcere. Analisi dello stato di salute delle persone detenute. Milano: FrancoAngeli.

Esposito, M. (2015). Women in Prison: Unhealthy Lives and Denied Well-Being between Loneliness and Seclusion. Crime, Law and Social Change, 63, 137-158.

https://doi.org/10.1007/s10611-015-9561-y 
Esposito, M. (2016). Il doppio fardello. Narrazioni di solitudine e malattia di persone detenute. Padova: Cedam.

Fazel, S. et al. (2008). Suicide in Prisoners: A Systematic Review of Risk Factors. The Journal of Clinical Psychiatry, 69, 1721-1731. https://doi.org/10.4088/JCP.v69n1107

Fornari, F. (1970). Nota sulla psicoanalisi del suicidio. Milano: Feltrinelli.

Foucault, M. (1975). Surveiller et punir. Naissance de la prison. Paris: Gallimard.

Gibbs, J. P., \& Martin, W. T. (1964). Status integration and suicide. Eugene: University of Oregon Press.

Goetting, A. (1983). The Elderly in Prison: Issues and Perspectives. Journal of Research in Crime and Delinquency, 20, 291-309. https://doi.org/10.1177/002242788302000209

Goffman, E. (1961). Asylums. Essays on the Social Situation of Mental Patients and Other Detainees, New York: Anchor Books, Doubleday \& Company, Inc.

Ham, J. N. (1976). The Forgotten Minority. An Exploration of Long Term Institutionalized Aged and Aging Male Prison Inmates. Unpublished PhD Thesis, Michigan: University of Michigan.

Harris, F., Hek, G., \& Condon, L. (2007). Health Needs of Prisoners in England and Wales: The Implications for Prison Healthcare of Gender, Age and Ethnicity. Health and Social Care in the Community, 15, 56-66.

Huey, P., \& Mcnulty, T. (2005). Institutional Conditions and Prison Suicide: Conditional Effects of Deprivation and Overcrowding. The Prison Journal, 4, 490-514. https://doi.org/10.1177/0032885505282258

Krajick, K. (1979). Growing Old in Prison. Corrections Magazine, 5, 33-46.

Kupers, T. (1999). Prison Madness: The Mental Health Crisis behind Bars and What We Must Do about It. San Francisco, CA: Jossey-Bass.

Liebling, A. (1999). Prison Suicide and Detainee Coping. Crime and Justice, 26, 283-359. https://doi.org/10.1086/449299

Lindquist, C. H. (2000). Social Integration and Mental Well-Being among Jail Detainees. Sociological Forum, 15, 431-455.

Malloch, M. S. (2000). Caring for Drug Users? The Experiences of Women Detainees. The Howard Journal, 39, 354-368. https://doi.org/10.1111/1468-2311.00175

Manconi, L., Anastasia, S., Calderone, V., \& Resta, F. (2015). Abolire il carcere. Milano: Chiarelettere.

Maris, R. W. (1981). Pathways to Suicide: A Survey of Self-Destructive Behaviors. Baltimore, MD: Johns Hopkins University Press.

Marshall, T., Simpson, S., \& Stevens, A. (2000). Health Care in Prisons: A Health Care Needs Assessment. Birmingham: University of Birmingham.

McCallum, A. (1995). Healthy Prisons: Oxymoron or Opportunity? Critical Public Health, 6, 4-15. https://doi.org/10.1080/09581599508409068

Mosconi, G. (2014). Gli indicatori sulla realtà carceraria in Italia, tra interventi legislativi e funzionalità strutturali. Democrazia e diritto, 3, 64-83.

Paton, J., \& Jenkins, R. (2005). Suicide and Suicide Attempts in Prison. In K. Hawton (Ed.), Prevention and Treatment of Suicidal Behaviour: From Science to Practice (pp. 307-334). Oxford: University Press. https://doi.org/10.1093/med/9780198529767.003.0018

Rabe, K. (2012). Prison Structure, Detainee Mortality and Suicide Risk in Europe. International Journal of Law and Psychiatry, 35, 222-230. 
https://doi.org/10.1016/j.ijlp.2012.02.012

Sarzotti, C. (2007). I medici penitenziari tra istanze securitarie e paradigma del rischio: Un' indagine empirica. In M. Esposito (Ed.), Malati in Carcere. Analisi dello stato di salute delle persone detenute (pp. 160-194). Milano: FrancoAngeli.

Serge, V. (1970). Men in Prison. London: Gollancz.

Shaw, J., Baker, D., \& Hunt, I. (2004). Suicide by Detainees. British Journal of Psychiatry, 184, 263-267. https://doi.org/10.1192/bjp.184.3.263

Shneidman, E. S. (1985). The Definition of Suicide. New York: Wiley.

Tatarelli, R., Mancinelli, I., Taggi, F., \& Polidori, G. (1999). Prison Suicides in Italy in 1996-1997. European Psychiatry, 14, 109-110.

Watson, R., Stimpson, A., \& Hostick, T. (2004). Prison Health Care: A Review of the Literature. International Journal of Nursing Studies, 41, 119-128.

https://doi.org/10.1016/S0020-7489(03)00128-7

World Health Organization (2007). Preventing Suicide in Jails and Prisons. Geneve: WHO. 